\title{
Phytochemical Profile, Antioxidant Activity and Cell Line Study of Marine Red Macroalgae Eucheuma cottonii on Lung A-549 Cancer Cells
}

\author{
Ade Arsianti ${ }^{1,2, *}$, Gerry Kurniawan ${ }^{3}$, Nadzila Anindya Tejaputri ${ }^{3}$, Fona Qorina ${ }^{3}$, Qotrunnada Fithrotunnisa ${ }^{3}$, \\ Norma Nur Azizah', ${ }^{2}$ Ajeng Megawati Fajrin'
}

\section{Ade Arsianti ${ }^{1,2, *}$, Gerry \\ Kurniawan ${ }^{3}$, Nadzila Anindya \\ Tejaputri ${ }^{3}$, Fona Qorina ${ }^{3}$, \\ Qotrunnada Fithrotunnisa3, \\ Norma Nur Azizah², Ajeng \\ Megawati Fajrin ${ }^{1}$}

'Department of Medical Chemistry, Faculty of Medicine, University of Indonesia, Jakarta, INDONESIA.

${ }^{2}$ Drug Development Research Cluster, Indonesia Medical Education and Research Institute (IMERI), Faculty of Medicine,

University of Indonesia, Jalan Salemba Raya 6 Jakarta 10430, INDONESIA.

${ }^{3}$ Medical Student, Faculty of Medicine University of Indonesia, Jakarta, INDONESIA.

\section{Correspondence}

\section{Dr. Ade Arsianti}

Department of Medical Chemistry, Faculty of Medicine University of Indonesia

Depok, INDONESIA.

Phone no: +6281312581253

E-mail: arsi_ade2002@yahoo.com

History

- Submission Date: 20-12-2019;

- Review completed: 02-01-2020;

- Accepted Date: 16-01-2020.

DOI : 10.5530/pj.2020.12.43

Article Available online http://www.phcogj.com/v12/i2

\section{Copyright}

(C) 2020 Phcogj.Com. This is an openaccess article distributed under the terms of the Creative Commons Attribution 4.0 International license.

\begin{abstract}
Introduction: In this century, cancer has increased in incidence and become one of the deadliest disease in the world. However, to date, lung cancer treatments are still not fully effective, quite expensive and very exhaustive for the patient. Eucheuma cottonii is an abundant marine red macroalgae in Indonesia which have a potential anti-lung cancer properties. Aim of this research is to determine phytochemical profile of Eucheuma cottonii extracts, as well as to evaluate its antioxidant and cytotoxic effects on Lung A-549 cancer cells. Methods: Eucheuma cottonii obtained from Sorong beach, West Papua Province, Indonesia, were extracted with three different solvents, that is ethanol, ethylacetate, and n-hexane. These three Eucheuma cottonii extracts were identified for its phytochemical profiles, antioxidant activity by DPPH (2,2-diphenyl-1-picrylhydrazyl) assay, and cytotoxic activity on lung A-549 cells by MTT (3-[4,5-dimethylthiazol-2-yl]-2,5-diphenyltetrazolium bromide) assay. Results: Phytochemical analysis revealed that Eucheuma cottonii contains metabolites of triterpenoid and alkaloid. Antioxidant activity evaluation showed ethanol extract of Eucheuma cottonii has $\mathrm{IC}_{50}$ value of $559.76 \mu \mathrm{g} / \mathrm{mL}$ against DPPH free radical. Whereas cytotoxicity evaluation showed that ethanol extract and ethylacetate extract of Eucheuma cottonii have cytotoxic effects on Lung A-549 cancer cells, with $\mathrm{IC}_{50}$ value of $251.73 \mu \mathrm{g} / \mathrm{mL}$ and $261.41 \mu \mathrm{g} / \mathrm{mL}$, respectively. Conclusion: These results suggesting that Eucheuma cottonii extract could be further developed as a natural anti-lung cancer agent.
\end{abstract}

Key words: Eucheuma cottonii, Phytochemical, Antioxidant, Cell line study, Lung A-549 cells.

\section{INTRODUCTION}

Cancer is abnormal cell growth and has become one of the major non-communicable diseases (NCDs) that has reduced people life expectancy in this century. ${ }^{1,2}$ In 2018 , cancer has increased by 18.1 million cases and has caused 9.6 million the total death of the world's population so that it becomes second deadliest disease in the world. One of the most common and deadly cancers for both men and women in the world is lung cancer, with an incidence rate of $11.6 \%$ of total cancer cases and contributes $18.4 \%$ of total cancer deaths. ${ }^{2}$ In Indonesia, lung cancer is the highest cancer incidence in men and the first leading cause of death from cancer in men $(21.8 \%)$ and second in women $(9.1 \%)^{3}$, which prompted us to conduct specific cell line study of marine seaweed on lung cancer. This high incidence of lung cancer in Indonesia reached a prevalence of $36.3 \%$ in 2013 , that is caused by high smoking behavior. It is known that smoking is the biggest risk factor (80-90\%) of lung cancer. Thus, Indonesia places the third rank in the world for number of smokers. ${ }^{4,5}$

Treatments of lung cancer are surgery, chemotherapy, radiation and targeted therapy. ${ }^{6}$ However, these various treatments have some side effects, the emergence of resistance, toxicity, and the prognosis of treatment is still low with an average 5-year survival rate around $16 \% .^{7}$ Based on these facts, discovering of more effective, less side effect and inexpensive anti-lung cancer agent is needed. Seaweed or marine macroalgae are the marine species which have been commonly used as food and traditional medicine, especially in the Asian continent. ${ }^{8}$ Marine algal had shown biological activities as anti-inflammatory, anticoagulant, antioxidant, antiviral and anticancer, so that it has become promising candidate for the new bioactive compound used in medicines. ${ }^{8,9}$ One species of the marine red macroalgae which potential to be developed as an anticancer agent is Eucheuma cottonii. Some previous researchers has reported that Eucheuma cottonii demonstrated anticancer activity against MCF-7 breast cancer cells, HCT-116 colorectal cancer cells, and HeLa cervical cancer cells. ${ }^{10-13}$ Beside that, Eucheuma cottonii are also widely cultivated in Indonesia, including in West Papua, with production level reached 6549 tons per year. ${ }^{14}$ The anticancer activity and the large production of Eucheuma cottoni in Indonesia has encouraged us to carry out phytochemical analysis, antioxidant activity, and cell line study of nutritious Eucheuma cottonii against lung A-549 cancer cells. 


\section{MATERIAL}

Marine red macroalgae Eucheuma cottonii (Figure 1) were collected from Sorong beach, West Papua, Indonesia in January 2019. Lung A-549 cancer cells are obtained from Bogor Agricultural Institute, Bogor, West Java, Indonesia.

\section{METHODS}

\section{Maceration and extraction of Eucheuma Cottonii}

Maceration and extraction technique of Eucheuma cottonii is adopted ${ }^{10}$, as follows. Eucheuma cottonii is dried and ground to form a powder. Amount of $100 \mathrm{~g}$ of Eucheumacottonii dried powder was then macerated with $500 \mathrm{~mL}$ of $\mathrm{n}$-hexane in a closed tube for 24 hours by occasional shaking. This maceration is done three times, the mixture was filtered. The filtrate is evaporated to give n-hexane extract of Eucheuma cottonii. Whereas the solid were macerated three times with $500 \mathrm{~mL}$ ethyl acetate for 24 hours. The mixture was filtered, the filtrate is collected and evaporated to produceethylacetate extract of Eucheuma cottonii. The solids were then macerated three times with $500 \mathrm{~mL}$ ethanol for 24 hours. The mixture was filtered, the filtrate is collected and evaporated to generate ethanol extract of Eucheuma cottonii. ${ }^{10}$

\section{Phytochemical test}

Phytochemical test are used to determine thesecondary metabolites containing in the extracts of Eucheuma cottoni. The phytochemical test procedure was carried out according to the method provided by Harborne (1987). ${ }^{10,11,15}$ Phytochemical denotes all the following mentioned parameters.

Test for saponin is carried out by shaking vertically $10 \mathrm{ml}$ of the sample solution in a test tube for 10 seconds and left it still for 10 seconds. Formation of stable foam as high as $1-10 \mathrm{~cm}$ for 10 minutes or more indicates the presence of saponin metabolites. Addition of 1 drop of $\mathrm{HCl} 2 \mathrm{~N}$ is done to ensure the foam still does not disappear, which confirm the presence of saponin.

Test for flavonoid is carried out by evaporating $1 \mathrm{ml}$ of the sample solution and continuing by adding of acetone, boric acid powder and oxalic acid. After that, the mixture is put into warm water at $60^{\circ} \mathrm{C}$ for 15 minutes. The mixture was then added with $10 \mathrm{ml}$ of ether and observe

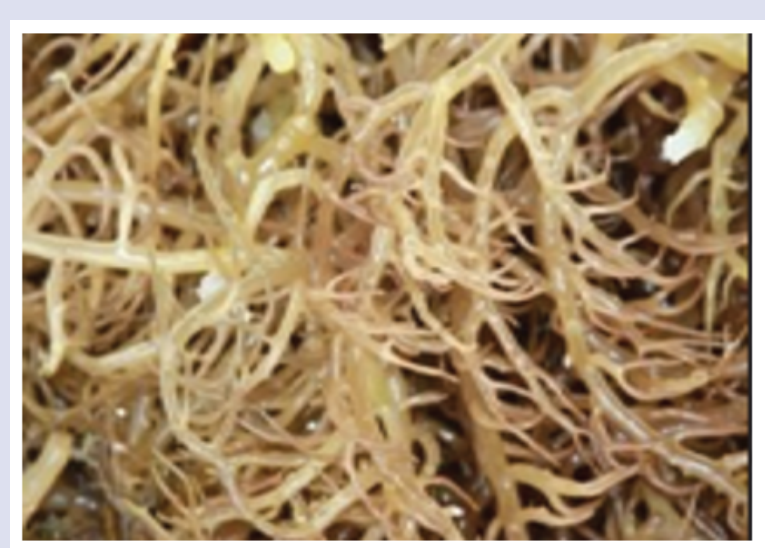

Figure 1. Eucheumacottonii.

Kingdom: Plantae

Division: Rhodophyta

Class: Rhodophyceae

Order: Gigantinales

Family: Solieracea

Genus: Eucheuma

Species: Eucheumacottonii it in UV light at $366 \mathrm{~nm}$. The appearance of the yellow fluorescence in the UV light indicates the presence of flavonoid.

Test for tannin is carried out by reacting $1 \mathrm{~mL}$ of sample solution with $10 \%$ of $\mathrm{FeCl}_{3}$ solution. Formation of dark blue or dark green color indicates the presence of tannin.

Test for glycoside is carried out by evaporating $1 \mathrm{~mL}$ of solution in warm water at $60^{\circ} \mathrm{C}$ for 15 minutes, then dissolving it into $5 \mathrm{~mL}$ of anhydrate acetic acid. Subsequently, concentrated sulfuric acid (10 drops) was added into the mixture. Formation of blue or green deposits indicate the presence of glycosides.

Test for triterpenoid and steroid were carried out using the Liebermann-Burchard reaction. Sample solution $(2 \mathrm{~mL})$ was evaporated in a porcelain glass. The residue was dissolved with anhydrous chloroform $(0.5 \mathrm{~mL})$ and acetic acid $(0.5 \mathrm{~mL})$. After that, $2 \mathrm{~mL}$ of concentrated sulfuric acid is added into the mixture through the tube wall. The formation of brown or purple rings indicates the presence of triterpenoids. Meanwhile, the formation of a blue green ring indicates the presence of steroids.

Test for alkaloid is done by evaporating $2 \mathrm{~mL}$ of sample solution on a porcelain. The residue were then added $2 \mathrm{~N}$ of $\mathrm{HCl}(5 \mathrm{~mL})$ and the mixture is divided into 3 different tubes. The first tube is a blank tube which only contains the mixture. In the second tube, 3 drops of Dragendorff's reagent was added into the mixture, and in the third tube, 3 drops of Mayer's reagent was added into the mixture. Formation of orange precipitates in the second tube or yellow precipitates in the third tube indicates the presence of alkaloids.

\section{Thin layer chromatography}

Thin Layer Chromatography (TLC) is an easy, inexpensive, and highsensitive technique, consisting of two phases, the stationary phase and the mobile phase. Stationary phase is a thin plate of silica gel material $\left(\mathrm{SiO}_{2}\right)$ or aluminum oxide, whereas the mobile phase is a mixture of eluent solution. ${ }^{16}$ In this work, a mixture of $n$-hexane and ethyl acetate with a ratio of 5:1 is used as a mobile phase. Each phytochemical compound in extract will have different adsorption and solubility in the two phases. Polar compounds in the extract will be adsorbed by the stationary phase, while the non-polar compounds will move at the stationary phase layer with different rates and distances due to its polarity and solubility in the mobile phase. UV light at $254 \mathrm{~nm}$ and 366 $\mathrm{nm}$ is used for visualization of spot's compound, and the Rf (retention factor) value of each spot's compound can be calculated by the following formulae. ${ }^{16}$

\section{$\mathrm{Rf}$ (retention factor) = Distance traveled by sample / distance traveled by solvent}

\section{Antioxidant activity evaluation by DPPH method}

DPPH method was carried out to determine the antioxidant properties of Eucheuma cottonii extracts. The procedure as follows, ethylacetate extract $(5 \mathrm{mg})$ and ethanol extract $(5 \mathrm{mg})$ of Eucheuma cottonii were placed into a separate test tube. Amount of $10 \mathrm{ml}$ of $75 \%$ ethanol was added into each of test tube to give ethylacetate and ethanol extracts of Eucheuma cottonii with the concentration of $500 \mu \mathrm{g} / \mathrm{mL}$. After that, each extract of Eucheuma cottonii with the concentration of $500 \mu \mathrm{g} / \mathrm{mL}$ was diluted with $75 \%$ of ethanol to produce six various concentrations of $6.25,12.5,25,50,100$ and $200 \mu \mathrm{g} / \mathrm{mL}$ of ethylacetate extract and etanol extract, respectively. Subsequently, DPPH solution $(0.1 \mathrm{mg} / \mathrm{mL})$ was added into to these six various concentrations of Eucheuma cottonii extracts. The mixture was then incubated in a dark condition at room temperature for 2 hours. The incubated mixture was then measured for its absorbance by a spectrophotometer UV-Vis at the wavelength of 
$517 \mathrm{~nm}$. Percentage of inhibition of the extract on DPPH free radical (antioxidant properties) is calculated with the formula:

\section{Percentage of DPPH Inhibition (\%) = (1 - (sample absorbance /absorbance blank)) $\times 100 \%$}

The antioxidant properties is expressed as $\mathrm{IC}_{50}$ value. Plotting of DPPH $\%$ inhibition of sample with the concentration will produce linear line equation of $\mathrm{Y}=\mathrm{ax}+\mathrm{b}$. The $\mathrm{IC}_{50}$ value of the sample could be determined by substituting $\mathrm{Y}$ coefficient with value of 50 to give the $\mathrm{x}$ value, which is equal to the $\mathrm{IC}_{50}$ value.

\section{Cytotoxic activity evaluation by MTT assay}

In this research, MTT assay is a colorimetric method that is used to measure proliferation, viability, and metabolic activity of lung A-549 cancer cells against Eucheuma cottonii extract. ${ }^{17}$ Extracts of Eucheuma cottonii were diluted until reached the concentrations of 1.56, 3.125, $6.25,12.5,25,50,100,200 \mu \mathrm{g} / \mathrm{mL}$. Extract samples with these various concentrations were added to the target cell culture of lung A-549 cancer cells. Then the cells were incubated for 48 hours at room temperature. Subsequently, $20 \mu \mathrm{l}$ of MTT solution with a concentration of $5 \mathrm{mg} / \mathrm{mL}$ in the phosphate-buffered saline solution was added to the incubated mixture. Afterwards, the mixture were reincubated for 4 hours. Then, the mixture is centrifuged and the medium was removed. Amount of $200 \mu$ dimethyl sulfoxide (DMSO) was added to the plate well to dissolve bluish purple sediments. The absorbance is read using at 590 $\mathrm{nm}$ on the microplate reader. ${ }^{10}$

Inhibition Rate(\%) $=1-\left(\frac{\text { Absorbance of Sample with Treatment }}{\text { Absorbance of Control }}\right) \times 100 \%$

IC $_{50}\left(50 \%\right.$ inhibitory concentration) was calculated using Bliss assay. ${ }^{10}$

\section{RESULTS AND DISCUSSION}

\section{Phytochemical profile of eucheumacottonii extracts}

Table 1 summarizes the phytochemical profile of Eucheuma cottonit extracts, which shows that all three type of Eucheuma cottonii extracts containmetabolitesof triterpenoids and alkaloids. Triterpenoids and alkaloids are compounds that are widely distributed in plants and marine algae. Triterpenoids are organic compounds that have a variety of structure. Some triterpenoid compounds are ursolic acid, oleanolic acid, betulinic acid, celastrol, andlupeol. These triterpenoid compounds have been shown anti-tumor and anti-inflammatory properties. Triterpenoids exhibited antitumor activity by inducing apoptosis, inhibiting NF- $\kappa \mathrm{B}$ activation, inhibiting cell signal transduction pathways and angiogenesis. ${ }^{18}$ Meanwhile, alkaloids are compounds bearing nitrogen atoms that have many biological activities, such as anti-asthma, analgesic effects, anti-cancer, antiproliferation and antimetastatic. Alkaloid compounds are indeed proven to have anticancer effects and have been developed into chemotherapy drugs such as camptothecin (topoisomerase I inhibitors) and vinblastine (interactions with tubulin). ${ }^{19}$

\section{Thin layer chromatography (TLC) analysis of Eucheumacottonii extract}

Appearance of TLC analysis of Eucheuma cottonii extracts is displayed in Figure 2, whereas retention factors of phytochemical components containing in each extract is summarized in Table 2. TLC analysis shows that ethanol extract of Eucheuma cottonii has 2 spots of phytochemical compounds, ethyl acetateextract has 3 spots of phytochemical compounds, and n-hexaneextract has only 1 spot of phytochemical compound. It seems that polar extractof ethanol and semi-polar extract of ethylacetate have similar phytochemical compounds at $\mathrm{Rf}$ of 0.54 and 0.84 . It happened because ethanol extracts
Table 1: Phytochemical profile of Eucheumacottonii.

\begin{tabular}{llll}
\hline Metabolites & Extract & & \\
\cline { 2 - 4 } & n-Hexane & Ethylacetate & Ethanol \\
\hline Saponin & - & - & - \\
Flavonoid & - & - & - \\
Triterpenoid & + & + & + \\
Steroid & - & - & - \\
Alkaloid & + & + & + \\
Tannin & - & - & - \\
Glycoside & - & - & - \\
\hline
\end{tabular}

Table 2: Retention factor (Rf) of phytochemicalcomponens in Eucheuma cottonii extracts.

\begin{tabular}{llll}
\hline \multirow{2}{*}{ Extract } & \multicolumn{2}{l}{ Rf Value } & 3 \\
\cline { 2 - 4 } & 1 & 2 & - \\
Ethanol & 0.54 & 0.84 & 0.93 \\
Ethyl Acetate & 0.54 & 0.84 & - \\
n-Hexane & 0.72 & - & \\
\hline
\end{tabular}

\section{${ }^{*} \mathrm{Rf}=$ Retentionfactor}

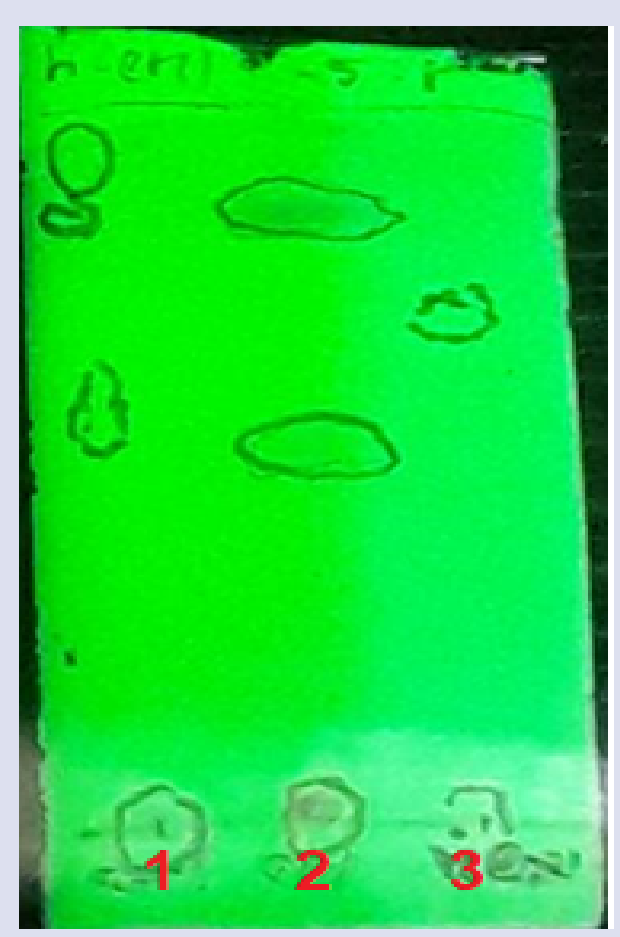

Figure 2: TLC analysis of E. cottonii. 1: ethanol extract, 2: ethylacetate extract, 3: n-hexane extract.

tend to contain polar chemical compounds and ethyl acetate extracts tend to contain semipolar compounds. Meanwhile, non-polar extract of n-hexane contains only one non-polar chemical compounds at Rfof 0.72 , confirming that it is not similar with phytochemical compound containing in ethanol and ethylacetate extract.

\section{Antioxidant activity of Eucheuma cottonii extracts}

Table 3 displays antioxidant activity of Eucheuma cottonii extracts and ascorbic acid (as a positive control) on DPPH free radical, which is expressed as $\mathrm{IC}_{50}$ value. Antioxidant activity of the test sample on DPPH can be categorized based on the $\mathrm{IC}_{50}$ value, as follows: $\mathrm{IC}_{50}$ value $\leq 100$ $\mu \mathrm{g} / \mathrm{mL}$ is assignedas an active antioxidant, whereas inactive antioxidant if $\mathrm{IC}_{50}$ value $\geq 200 \mu \mathrm{g} / \mathrm{mL}$ is assigned as inactive antioxidant. ${ }^{20}$ Ascorbic acid has very active antioxidant activity on $\mathrm{DPPH}$ with $\mathrm{IC}_{50}$ value of $6.46 \mu \mathrm{g} / \mathrm{mL}$. IC ${ }_{50}$ value for the ethanol extract was $559.76 \mu \mathrm{g} / \mathrm{mL}$ 
and ethylacetate extract was $41482.81 \mu \mathrm{g} / \mathrm{mL}$ on $\mathrm{DPPH}$ free radical. Therefore, both extracts did not have antioxidant activity on DPPH free radical. It seems that antioxidant activity of Eucheuma cottonii depend on the solvent used for extraction. Ethanol as polar solvent has more active as an antioxidant than ethylacetate as semi-polar solvent, because ethanol can dissolve more polar compound such as polyphenolic which possess antioxidant or free radical scavenging activity. ${ }^{20}$

\section{Cytotoxic effect of Eucheuma cottonii extracts against lung A-549 cancer cells}

Figure 3 shows the relationship between concentration of Eucheuma cottonii extract and its percentage of inhibition against lung A-549 cancer cells. In general, the percentage of inhibition against lung A-549 cancer cells increases by increasing the concentration of Eucheuma cottonii extract (concentration-dependent). Eucheuma cottonii extracts inhibit the growth of lung A-549 cancer cells at the concentration of $3.125 \mu \mathrm{g} /$ $\mathrm{mL}$ and reach a maximum inhibition $(50.7 \%)$ at the concentration of $200 \mu \mathrm{g} / \mathrm{mL}$.

Table 4 displays cytotoxic effect of Eucheuma cottonii extracts against lung A-549 cancer cells, expressed in $\mathrm{IC}_{50}$ value, which is the median inhibitory concentration of the extract that causes $50 \%$ inhibition of lung cancer cell growth. The smaller $\mathrm{IC}_{50}$ value, the greatercytotoxic effect of the extract against lung A-549 cells. In this research, $\mathrm{IC}_{50}$ value (x) was obtained by substituting $y$ in linear regression equation of $y=a x+b$ with value of 50 . Linear regression equation was generated by plotting of concentration of the extract in $\mathrm{x}$ axis with absorbance value in y axis.According to Atjanasuppat et. al., the level of cytotoxic effect of the tested extract is classified based on $\mathrm{IC}_{50}$ values, in which, it can be divided into 4 classes, as follows: $\mathrm{IC}_{50}$ value $\leq 20 \mu \mathrm{g} / \mathrm{mL}$ is classified to have a strong cytotoxic effect; $\mathrm{IC}_{50}$ value ranging from 20 to $100 \mu \mathrm{g} / \mathrm{mL}$ is classified to have a moderate cytotoxic effect; $\mathrm{IC}_{50}$ value ranging from 100 to $1000 \mu \mathrm{g} / \mathrm{mL}$ is classified to have a weak cytotoxic effect; $\mathrm{IC}_{50}$ value over $1000 \mu \mathrm{g} / \mathrm{mL}$ is classified to have no cytotoxic effect. ${ }^{21}$

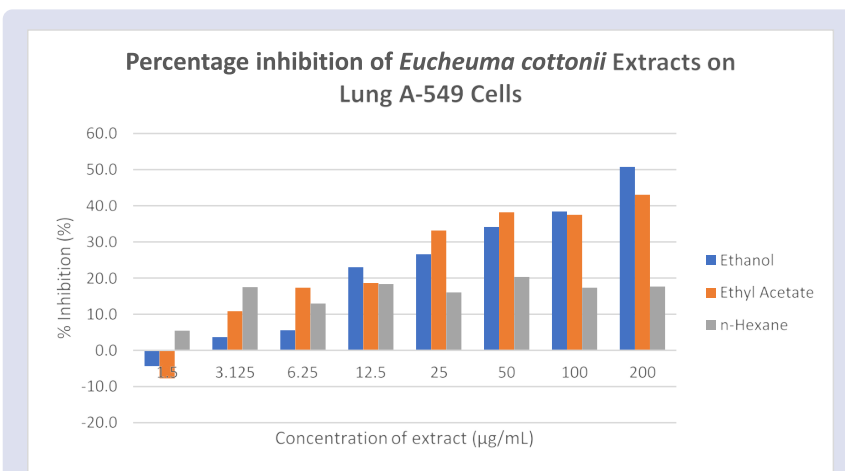

Figure 3: The relationship between concentration of Eucheuma cottonii extracts and its percentage inhibition on lung A-549 cancer cells.

Table 3: Antioxidant activity of Eucheuma cottonii extracts and ascorbic acid on DPPH.

\begin{tabular}{cc}
\hline Tested Sample & $\mathrm{IC}_{50}(\mu \mathrm{g} / \mathrm{mL})$ \\
\hline Ascorbic acid (positive control) & 6.46 \\
Ethylacetate extract of $E$. cottonii & 41482.81 \\
Ethanol extract of E. cottonii & 559.76 \\
\hline
\end{tabular}

Table 4: Cytotoxic effect of Eucheuma cottonii extracts and cisplatin against lung $A-549$ cells.

\begin{tabular}{cc}
\hline Extract & $\mathrm{IC}_{50}(\mu \mathrm{g} / \mathrm{mL})$ \\
\hline Ethanol & 251.73 \\
Ethyl acetate & 261.41 \\
n-Hexane & 3508 \\
Cisplatin (positive control) & 3.61 \\
\hline
\end{tabular}

As shown in Table 4, cisplatin as positive control with $\mathrm{IC}_{50}$ value of 3.61 $\mu \mathrm{g} / \mathrm{mL}$ has the strongest cytotoxic effect on lung A-549 cells. Ethanol and ethylacetate extracts of Eucheuma cottonii exhibited cytotoxic effect on lung A-549 cells with $\mathrm{IC}_{50}$ values are $251.73 \mu \mathrm{g} / \mathrm{mL}$ and $261.41 \mu \mathrm{g} /$ $\mathrm{mL}$, respectively. In contrast with ethanol and ethylacetate extracts, n-hexane extract of Eucheuma cottonii with $\mathrm{IC}_{50}$ value of $3508 \mu \mathrm{g} / \mathrm{mL}$, did not showed cytotoxic effect against lung A-549 cancer cells. This result indicating that semi-polar and polar compounds in ethylacetate and etanol extracts of Eucheuma cottonii are more effective as an antilung cancer on A-549 cells compared to non-polar compounds in n-hexane extract of Eucheuma cottonii.

\section{CONCLUSION}

Marine red macroalgae Eucheuma cottonii demonstrated cytotoxic effect against lung A-549 cancer cells with $\mathrm{IC}_{50}$ value of $251.73 \mu \mathrm{g} /$ $\mathrm{mL}$ for ethanol extract and $261.41 \mu \mathrm{g} / \mathrm{mL}$ for ethanol extract. Thus, ethylacetate and ethanol extracts of Eucheuma cottonii are potential to be further developed as an anti-lung cancer agent.

\section{ACKNOWLEDGEMENT}

We express our special thanks of gratitute to Ministry of Research and Technology and Higher Education (Kemenristek-DIKTI) of Republic of Indonesia, and Directorate of Research and Public Service, University of Indonesia (DRPM UI), for the PITTA B and PDUPT research grants, fiscal year 2019 (contract number of PDUPT research grant: 1525/ UN2.R3.1/HKP05.00/2019).

\section{CONFLICTS OF INTEREST}

Authors declare no conflicts of interest.

\section{ABBREVIATIONS}

TLC: Thin layer chromatography; DPPH: (2,2-diphenyl1-picrylhydrazyl) MTT:(3-(4,5-Dimethylthiazol-2-yl)-2,5Diphenyltetrazolium Bromide); $\mathbf{I C}_{50}$ : median Inhibitory Concentration; $\boldsymbol{\mu g} / \mathbf{m L}$ : microgram/milliliter;g: gram; $\mathbf{m L}$ : millimeter; N: Normality; UV-Vis: Ultra violet-Visible, RPMI: Rosewell Park Memorial Institute; h: hour; PBS: Phosphate-Buffered Saline; ${ }^{\circ} \mathbf{C}$ : degree Celsius; $\boldsymbol{\mu L}$ : microliter; $\mathbf{C O}_{2}$ : Carbon dioxide; Rf: Retention factor; USA: United States of America.

\section{REFERENCES}

1. WHO | Cancer. WHO . 2018 [cited 2019 Jan 9]; Available from: https://www. who.int/cancer/en/

2. Bray F, Ferlay J, Soerjomataram I, Siegel RL, Torre LA, Jemal A. Global cancer statistics 2018: GLOBOCAN estimates of incidence and mortality worldwide for 36 cancers in 185 countries. CA Cancer J Clin. 2018;68(6):394-424.

3. Indonesia KKR. Pedoman Nasional Pelayanan Kedokteran: Kanker Paru. 2017.

4. Badan Penelitian Dan Pengembangan Kesehatan Kementerian Kesehatan Republik Indonesia. Riset Kesehatan Dasar 2013. Jakarta: Ministry of Health; 2013.

5. PrabandariYS, Dewi A. How do Indonesian youth perceive cigarette advertising? A cross-sectional study among Indonesian high school students. Glob Health Action . 2016;9:30914.

6. Latimer KM, Mott TF. Lung Cancer: Diagnosis, Treatment Principles, and Screening. Am Fam Physician. 2015;91(4):250-6.

7. Huang C-Y, Ju D-T, Chang C-F, Muralidhar Reddy P, Velmurugan BK. A review on the effects of current chemotherapy drugs and natural agents in treating nonsmall cell lung cancer. BioMedicine. 2017;7(4):23.

8. Moussavou G, Kwak DH, Obiang-Obonou BW, Maranguy CAO, DinzounaBoutamba S-D, Lee DH, et al. Anticancer effects of different seaweeds on human colon and breast cancers. Mar Drugs. 2014;12(9):4898-911.

9. Brown EM, Allsopp PJ, Magee PJ, Gill Cl, Nitecki S, Strain CR, et al. Seaweed and human health. Nutr Rev. 2014;72(3):205-16.

10. Arsianti AA, Fadilah F, Suid K, Yazid F, Wibisono LK, Azizah NN, et al Phytochemical composition and anticancer activity of seaweeds ulva lactuca and eucheuma cottonii against breast MCF-7 and colon HCT-116 cells. Asian J Pharm Clin Res. 2016;9(6):115. 
11. Arsianti A, Aziza YA, Kurniasari KD, Mandasari BK, Masita R, Zulfa FR, et al. Phytochemical Test and Cytotoxic Activity of Macroalgae Eucheuma cottonii against Cervical HeLa Cells. Pharmacognosy Journal. 2018;10(5):1012-7.

12. Lee JW, Teo SS. In-vitro cytotoxicity and anticancer activity of eucheuma cottonii extracts against hela cell line. Malaysian Journal of Science. 2013;32:213-20.

13. Lee JW, Wang JH, Ng KM, Tan CH, Teo SS. In-Vitro Anticancer Activity Of Eucheuma Cottonii Extracts Against Hela Cell Line, Humn Lung Carcinoma Cell Line (Sk-Lu-1), Human Colon Carcinoma Cell Line (Hct-116), and Fibroblast. IJCMS. 2015;1(2):69-73.

14. Kementrian Perdagangan Republik Indonesia. Rumput Laut Indonesia . Jakarta: Kementrian Perdagangan RI; 2013

15. Harborne J.B. Metode Fitokimia. Penuntun Cara Modern Menganalisis Tumbuhan, 1987, 2018:27, Penerbit ITB Bandung
16. Santiago M, Strobel S. Thin Layer Chromatography. Methods Enzymol. 2013;533:303-24.

17. Kuete V, Karaosmanoğlu O, Sivas H. Anticancer Activities of African Medicinal Spices and Vegetables. In: Medicinal Spices and Vegetables from Africa. Elsevier; 2017;271-97.

18. Petronellia A, Pannitterib G, Testaa U. Triterpenoids as new promising anticancer drugs. Anticancer Drugs. 2009;20(10):880-92.

19. Lu JJ, Bao JL, Chen XP, Huang M, Wang YT. Alkaloids isolated from natural herbs as the anticancer agents. Evidence-Based Complement Altern Med. 2012;2012.

20. Fitriana WD, Ersam T, Shimizu K, Fatmawati S. Antioxidant Activity of Moringa oleifera Extracts. Indones J Chem. 2016;16(3):297-301.

21. Atjanasuppat K, Wongkham W, Meepowpan $P_{1}$ Kittakoop $P_{\text {, Sobhon } P_{1}}$ Bartlett $A$, et al. In vitro screening for anthelmintic and antitumour activity of ethnomedicinal plants from Thailand. J Ethnopharmacol. 2009;123(3):475-82.

\section{GRAPHICAL ABSTRACT}

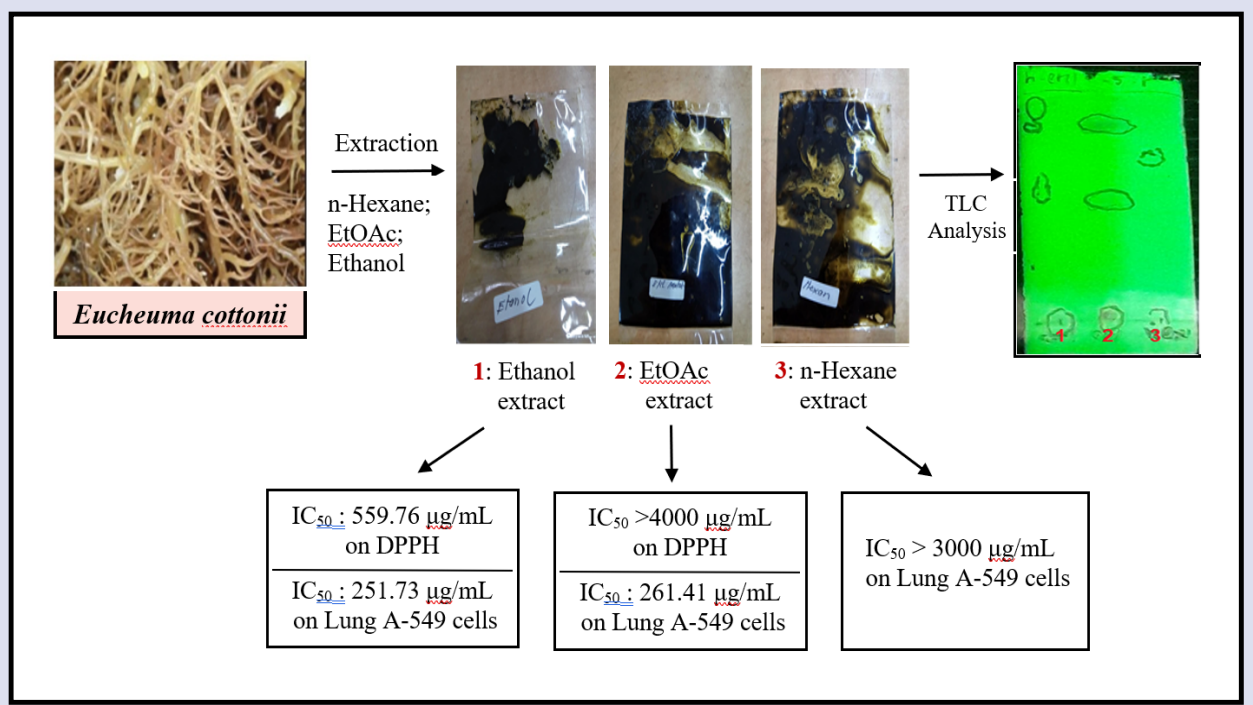

\section{SUMMARY}

Red algae Eucheuma cottonii from Sorong beach, West Papua Province, bearing three phytochemical compounds. Ethanol and ethylacetate extracts of Eucheuma cottonii have no antioxidant activity on DPPH free radical. In contrast to antioxidant activity, both ethanol and ethylacetate extracts of Eucheuma cottonii showed cytotoxic effect against lung A-549 cancer cells with IC ${ }_{50}$ value of $251.73 \mu \mathrm{g} / \mathrm{mL}$ and $261.41 \mu \mathrm{g} / \mathrm{mL}$, respectively.

\section{ABOUT AUTHORS}

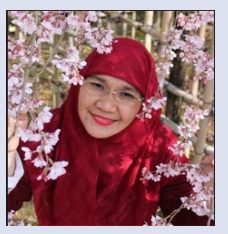

Dr. Ade Arsianti: Lecture and Researcher at Medical Chemistry and Drug Development Research Center, Indonesian Medical Education and Research Institute, Faculty of Medicine, Universitas Indonesia. Research interest in medicinal chemistry, synthetic organic chemistry, marine and herbal natural product chemistry.

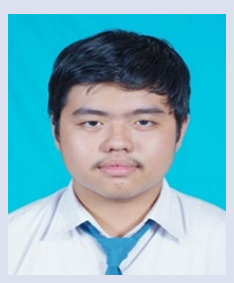

Gerry Kurniawan: Medical Student, Faculty of Medicine, Universitas Indonesia. Research interest in cardiology, pulmonology, and oncology. 


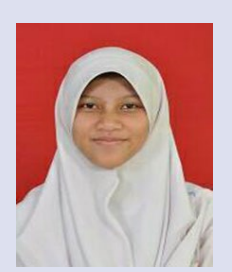

Nadzila Anindya Tejaputri: Medical Student, Faculty of Medicine, Universitas Indonesia. Research interest in herbal medicine, cancer biology, pediatric disease, and mental health science.

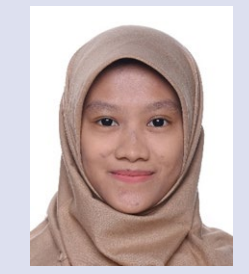

Fona Qorina: Medical Student, Faculty of Medicine, Universitas Indonesia. Research interest in herbal medicine, cancer biology, cardiovascular and metabolic disease.

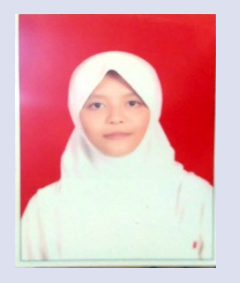

Qotrunnada Fithrotunnisa: Medical Student, Faculty of Medicine, Universitas Indonesia. Research interest in herbal medicine and cancer biology.

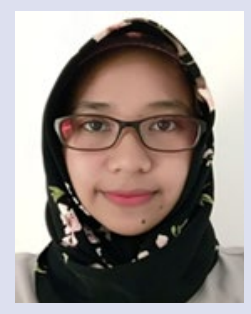

Norma Nur Azizah., S.Si: Researcher at Drug Development Research Center, Indonesian Medical Education and Research Institute, Faculty of Medicine, Universitas Indonesia. Research interest in tissue culture, analytical chemistry, and natural product chemistry in drug development.

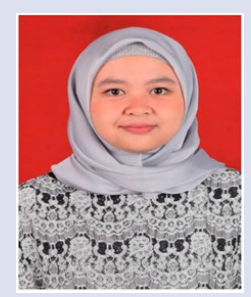

Ajeng Megawati Fajrin: Researcher at Department of Medical Chemistry, Faculty of Medicine, Universitas Indonesia. Research interest in tissue culture, analytical chemistry, and natural product chemistry.

Cite this article: Arsianti A, Kurniawan G, Tejaputri NA, Qorina F, Fithrotunnisa Q, Azizah NN, et al. Phytochemical Profile, Antioxidant Activity and Cell Line Study of Marine Red Macroalgae Eucheuma cottonii on Lung A-549 Cancer Cells. Pharmacog J. 2020;12(2):276-81. 